Article

\title{
In Situ Synthesis of Au Nanoparticles on Viscose Cellulose Sponges for Antibacterial Activities
}

\author{
Mingjing Shan ${ }^{1,2}$, Chang Liu ${ }^{1,2}{ }^{3}$, Lei Shi ${ }^{2}$, Lei Zhang ${ }^{2}$, Yuan Lin ${ }^{2}$, Shuo Zhang ${ }^{2}$, \\ Zhenjun Zhu ${ }^{2}$, Xiaoyin Wang ${ }^{3, *}$ and Xupin Zhuang ${ }^{1,2, *(D)}$ \\ 1 State Key Laboratory of Separation Membranes and Membrane Processes, Tianjin Polytechnic University, \\ Tianjin 300387, China \\ 2 School of Textile Science and Engineering, Tianjin Polytechnic University, Tianjin 300387, China \\ 3 School of Mathematical Sciences, Tianjin Polytechnic University, Tianjin 300387, China \\ * Correspondence: wxywxq@163.com (X.W.); zhxupin@tjpu.edu.cn (X.Z.); Tel.: +86-22-8395-5353 (X.Z.); \\ Fax: +86-22-8395-5287 (X.Z.)
}

Received: 17 June 2019; Accepted: 6 July 2019; Published: 1 August 2019

check for updates

\begin{abstract}
Antibacterial viscose cellulose sponges (VCSs) were fabricated by heating cellulose xanthogenate (viscose) containing $\mathrm{HAuCl}_{4} \cdot \mathrm{nH}_{2} \mathrm{O}$. Viscose was used as the reducing agent and stabilizer for the in situ synthesis of Au nanoparticles (AuNPs) onto the VCSs. The morphology, structures, thermal properties, mechanical performance, and antibacterial activities of the sponges were investigated. Results indicate that AuNPs were uniformly immobilized in the VCSs, and the resulting complexes (AuNPs@VCSs) showed enhanced thermal stability and mechanical properties. Additionally, the AuNPs@VCSs exhibited remarkable antibacterial activities, with zone of inhibition diameter of 35.7 and $37.1 \mathrm{~mm}$ for Staphylococcus aureus and Escherichia coli, respectively. The process is simple and applicable at the industrial level and can be applied to the fields of cleaning and sanitation.
\end{abstract}

Keywords: Au nanoparticles; cellulose; sponge; antibacterial activities

\section{Introduction}

Sponges have low-density, high-porosity, and large specific surface areas. At present, most commercial sponges are petrochemical-based and nonbiodegradable, thereby posing challenges on environmental pollution and resource management [1,2]. Cellulose, as the most abundant natural polymer on earth, has attracted immense attention and is considered an almost inexhaustible source of raw material for environmentally friendly and biocompatible products [3]. Recently, a series of direct-solvent systems have been introduced for cellulose, including $N$-methylmorpholine- $N$-oxide (NMMO), $\mathrm{LiCl} / \mathrm{N}, \mathrm{N}$-dimethylacetamide ( $\mathrm{LiCl} / \mathrm{DMAc}$ ), $\mathrm{NaOH} / \mathrm{urea} / \mathrm{H}_{2} \mathrm{O}$ solution, and ionic liquids, etc. [4-13]. These systems are used in the fabrication of cellulose sponges with porous structures, which have widespread applications in oil-water separation [14], thermal insulation [15], sound insulation [16], material packaging [17], and wound dressing [18].

On the other hand, the viscose process, developed over 100 years ago, remains the widely used and prevalent cellulose dissolution process for regenerated cellulose products. In the process, cellulose is reacted with $\mathrm{CS}_{2}$ to cellulose xanthogenate (viscose), which can be dissolved in aqueous $\mathrm{NaOH}$ and convert to regenerated cellulose by using an acidic solution. Although the process was criticized for high emissions of sulfur dioxide, it has gotten effective improvements in reducing pollution and the protection of the environment in the past few decades. Moreover, in the first decade of the 21st century, the global viscose staple capacity increased from approximately 1.5 million tons (an average of $7.7 \%$ per annum) to more than 3.5 million tons, which is an all-time record high [19]. Thus, developing cellulose sponges by using viscose is practically significant. Similar to sponge-forming process in direct-solvent 
systems, the viscose process produces viscose cellulose sponge (VCS) when a pore-forming agent is used in the regeneration process.

Nanoparticles, especially metal nanoparticles $(\mathrm{Ag}, \mathrm{Cu}$, and $\mathrm{Au})$, have widespread application in many modern technologies and have been used as antibacterial agents in several fields [20,21]. Gold nanoparticle (AuNP) is the most stable metal nanoparticle and exhibits antibacterial activity by attaching to bacterial membrane. AuNPs modify membrane potential, decrease ATP level, and inhibit the binding of tRNA to the ribosome [22]. AuNPs are highly effective against broad-spectrum microorganisms and bacterial species, viruses, and fungi. More importantly, AuNPs have considerable biocompatibility with various biomacromolecules and are nontoxic to human cells [23-25]. AuNPs have been incorporated into polymer matrix to acquire antibacterial ability [26]. However, polymer matrix incorporation may cause the aggregation of AuNPs owing to van der Waals interactions [27]. Applying polymers to stabilize metal nanoparticles generated by a suitable reduction method is an effective method for preventing unwanted agglomeration. In the reduction process, reducing agents, such as sodium citrate, are commonly used. Meanwhile, other oxygen-rich polymers can be used as reducing agents and stabilizers. In our previous work, microcrystalline chitosan was used to synthesize AgNPs at room temperature without any special treatment [28]. Cellulose stabilizes and reduces $\mathrm{Au}^{3+}$ to AuNPs in alkaline environments [29] and used in the fabrication of antibacterial cotton fabrics through the in situ synthesis of AuNPs [30,31].

Herein, a facile method for preparing composite VCSs with AuNPs (AuNPs@VCSs) by reducing $\mathrm{HAuCl}_{4} \cdot \mathrm{nH}_{2} \mathrm{O}$ in situ was proposed. The AuNPs with viscose were stabilized through a hydrothermal process. The formation, structures, and properties of the AuNPs and AuNPs@VCSs were examined and discussed.

\section{Materials and Methods}

\subsection{Materials}

Cellulose (degree of polymerization of 670) was supplied by CHENGDU GRACE Co. Ltd. (Chengdu, China). Gold chloride hydrate $\left(\mathrm{HAuCl}_{4} \cdot \mathrm{nH}_{2} \mathrm{O} \mathrm{M} . \mathrm{W}=339.79, \mathrm{Au} \geq 47.5 \%\right.$ ) was provided by Tianjin Kermel Chemical Reagents (Tianjin, China). Other materials, such as carbon disulfide $\left(\mathrm{CS}_{2}\right)$, sodium hydroxide $(\mathrm{NaOH})$, and Glauber salt, were purchased from Shanghai Aladdin Co. (Shanghai, China). Escherichia coli and Staphylococcus aureus were provided by the School of Biology Science, NanKai University, Tianjin, China.

\subsection{In Situ Synthesis of AuNPs onto VCS}

Viscose was prepared using a common process. Aqueous $\mathrm{NaOH}$ was added to cellulose pulp with stirring, then $\mathrm{CS}_{2}$ was added into the mixture. Cellulose was converted to cellulose xanthogenate with $\mathrm{CS}_{2} . \mathrm{HAuCl}_{4} \cdot \mathrm{nH}_{2} \mathrm{O}$, which is equivalent to $1.6-7.9 \mathrm{wt} . \%$ of cellulose, was added to viscose at room temperature. The mixture was subjected to homogeneous mixing. Then, Glauber salt crystals were added. The resulting mixture was placed in a water bath at $85 \pm 5^{\circ} \mathrm{C}$ for $4 \mathrm{~h}$ and then washed. The composite sponges were coded as AuNPs@VCS-1.67, AuNPs@VCS-4.85, and AuNPs@VCS-7.83 according to the weight $\left(1.67 \%, 4.85 \%\right.$, and $7.83 \%$, respectively) of $\mathrm{HAuCl}_{4} \cdot \mathrm{nH}_{2} \mathrm{O}$.

\subsection{Characterization}

\subsubsection{Structures and Morphologies of VCS and AuNPs@VCS}

The morphologies of VCS and AuNPs@VCS were characterized with a scanning electron microscope (Hitachi S-4800). XRD was performed by using an XRD spectrometer (D8 Discover with GADDS, $40 \mathrm{kV}, 40 \mathrm{~mA})$ from 10 to 80 with CuK $\alpha$ radiation $(\lambda=1.541 \AA)$. All VCS and AuNPs@VCS were confirmed by Fourier transform infrared spectroscopy (FTIR; Nicolet 6700, Waltham, MA, USA) and X-ray photoelectron spectroscopy (XPS; Thermo-VG Scientific Ltd., West Sussex, UK). 


\subsubsection{Performance of the VCSs and AuNPs@VCSs}

A universal testing machine (Instron3369, Canton, MA, USA) was used in the extension test of the sponges at room temperature and speed of $2 \mathrm{~mm} \mathrm{~min}^{-1}$. In this experiment, lump-shaped samples with the volume of $10 \mathrm{~mm} \times 30 \mathrm{~mm} \times 3 \pm 1 \mathrm{~mm}$ were placed in a dryer with distilled water at the bottom. Then, the samples were measured. All the samples were provided with a uniform load, and tensile strength was calculated at the linear range of the stress-strain curve. The thermal properties of the VCSs and AuNPs@VCSs were evaluated through high-resolution thermogravimetric analysis (STA409PC) from $30^{\circ} \mathrm{C}$ to $500{ }^{\circ} \mathrm{C}$ at $10^{\circ} \mathrm{C} \mathrm{min}^{-1}$. Water absorption was obtained through the gravimetric method, the weights of the VCSs and AuNPs@VCSs were measured for the calculation of water absorption. Before the testing, all the sponges were uniformly cut into $15 \mathrm{~mm} \times 15 \mathrm{~mm} \times 3 \pm 1$ $\mathrm{mm}$ strips. The weight of each dried sample was recorded as W1 (g). All the samples were placed in distilled water at room temperature. After $12 \mathrm{~h}$, the samples were removed at same time points, and excess moisture on the surface was removed with filter paper. The swollen sample weight was weighed and recorded as W2 (g). Water absorption was calculated as follows:

$$
\text { Water retention }(\%)=((\mathrm{W} 2-\mathrm{W} 1) / \mathrm{W} 1) \times 100
$$

The water retention faculty of the sponges was determined. VCS and AuNPs@VCS sponge samples were immersed in distilled water and then transferred into centrifuge tubes containing filter papers at the bottom. The parameter of the centrifugal machine was 3 min with a rate of $500 \mathrm{rpm}$, the weight of the wet sample was weighed and recorded as W3 (g). The property of water retention was calculated by using the following formula:

$$
\text { Water retention }(\%)=((\mathrm{W} 3-\mathrm{W} 1) / \mathrm{W} 1) \times 100
$$

The antimicrobial properties of the VCSs and AuNPs@VCSs were detected against Gram-negative bacteria E. coli and Gram-positive bacteria S. aureus through the disc diffusion method. The experimental process of disc diffusion was introduced as follows: To prepare bacterial cultures, we added bacteria to $100 \mathrm{~mL}$ of autoclaved nutrient broth and agitated the suspension on shaking water bath at $37^{\circ} \mathrm{C}$ overnight at $160 \mathrm{rpm}$. Exactly $200 \mu \mathrm{L}$ of the suspension was added to the as-prepared culture medium, which was dumped into a Petri dish after autoclave steam sterilization. The discs of the sponges $(\mathrm{D}=$ $14 \mathrm{~mm}$ ) were placed into the culture medium for $24 \mathrm{~h}$ at $37^{\circ} \mathrm{C}$ in an incubator. The inhibition zone diameters of the sponge samples against $S$. aureus and E. coli were measured [32,33].

Three specimens of same AuNPs@VCS were separately placed in bottles, which had three kinds of solutions $\left(\mathrm{H}_{2} \mathrm{O}, \mathrm{NaOH}\right.$, or $\left.\mathrm{CH}_{3} \mathrm{COOH}\right)$. Then, the bottles were fixed in shaker air bath (Julabo SW 20, Germany) and adjusted at constant shaking of $100 \mathrm{rpm}$ and temperature of $30 \pm 5^{\circ} \mathrm{C}$. After $48 \mathrm{~h}$, all the parts of the AuNPs@VCSs extracted, and the solutions were measured by UV-Vis. Shimadzu UV-Vis spectrophotometer (UH4150) was used to qualitatively confirm the presence of AuNPs in the reaction medium. Reaction solution had an absorption range of 510-560 nm (maximum at approximately 540 $\mathrm{nm}$ ) due to the surface Plasmon resonance band of the AuNPs [34].

\section{Results and Discussion}

\subsection{In-Situ Synthesis of AuNPs onto VCS}

Cellulose xanthogenate is unstable and can be regenerated to cellulose in acidic environment. This information is the theoretical basis of viscose fibers [35]. Cellulose xanthogenate can also be converted to cellulose through the hydrothermal process; hence, obtaining antibacterial AuNPs@VCSs by heating viscose containing $\mathrm{HAuCl}_{4} \cdot \mathrm{nH}_{2} \mathrm{O}$ is facile. Viscose is generally used as reducing agent and stabilizer for the in situ synthesis of AuNPs onto VCS, as shown in Figure 1. 

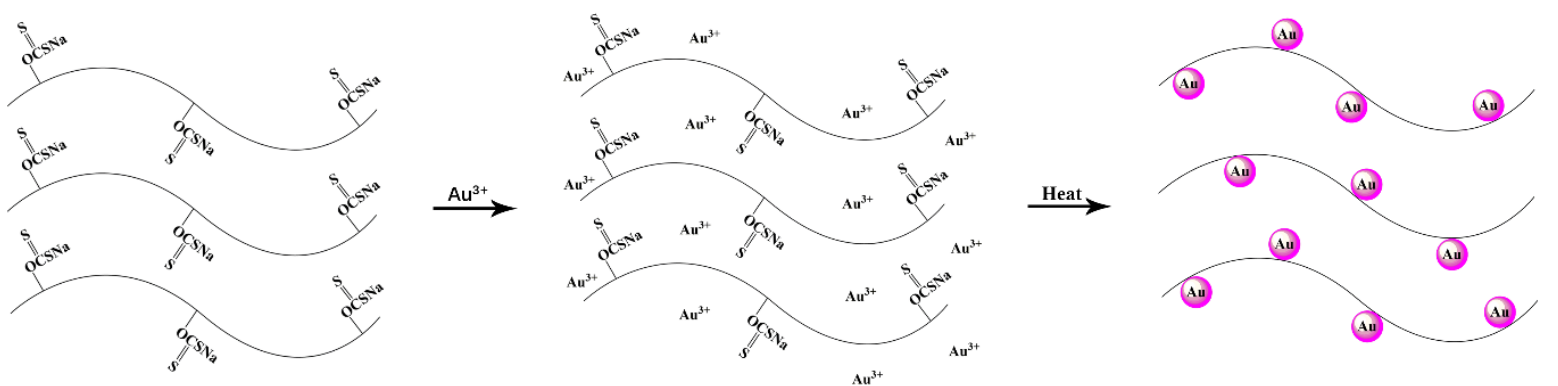

Figure 1. Schematic architecture of Au nanoparticles (AuNPs)@viscose cellulose sponge (VCS).

The cross profiles and surface morphology of the VCS and AuNPs@VCS samples were examined under different magnifications (Figure 2). All the cross profiles of the VCSs and AuNPs@VCSs had similar porous structures (Figure $2 \mathrm{a}, \mathrm{d}, \mathrm{g}, \mathrm{j}$ ). VCSs showed rough and clean surfaces (Figure 2c), whereas the AuNPs had uniform distributions on the surfaces of the AuNPs@VCSs after the hydrothermal process (Figure 2i,l); size increased with $\mathrm{HAuCl}_{4} \cdot \mathrm{nH}_{2} \mathrm{O}$ content (Figure $2 \mathrm{~m}, \mathrm{n}$ ). The AuNPs on the cross profile (Figure 2e,h,k) were significantly lesser than those on the surface (Figure 2f,i,l) probably because $\mathrm{Au}^{3+}$ had more contact area with the molecular chain of cellulose and AuNPs preferentially form on the surface.
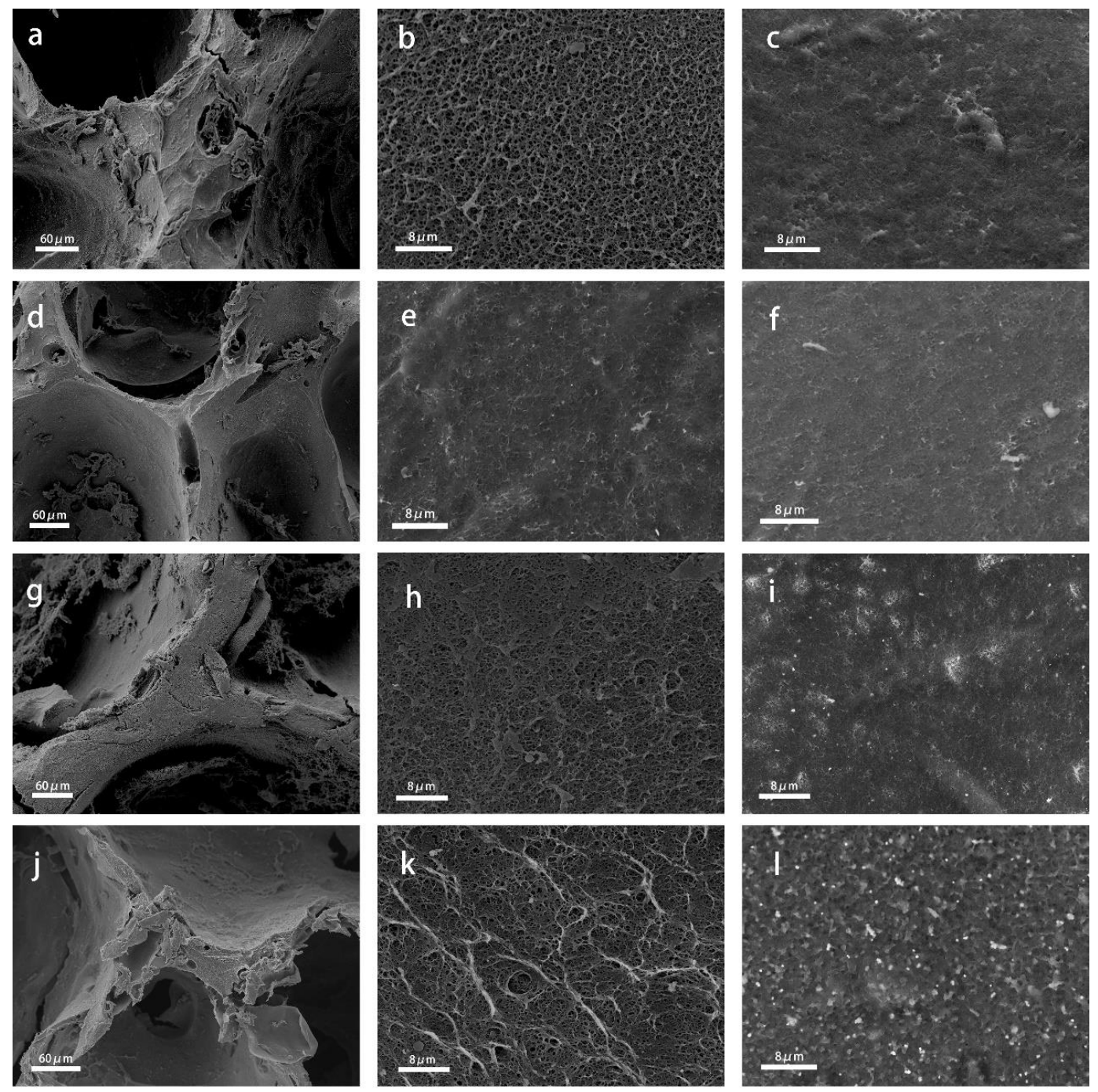

Figure 2. SEM images of cross profile and surface of VCS and AuNPs@VCS. 
The effect of AuNPs@VCS crystallinity, which consequently affected VCS properties and functionality, were examined through XRD. The XRD results are shown in Figure 3. The VCS showed two intense peaks, which represents regenerated cellulose at diffraction angle $\left(2 \theta=14.6^{\circ}\right.$ and $21.8^{\circ}$ ), corresponding to (101) and (002) reflection of cellulose II [36]. After the AuNPs were synthesized onto VCS, four additional peaks were recorded at $2 \theta=37.7^{\circ}, 43.8^{\circ}, 64.1^{\circ}$, and $77.2^{\circ}$, which were indexed to the (111), (200), (220), and (311) crystal planes of AuNPs [37,38]. The XRD results provided strong evidence of the presence of AuNPs.

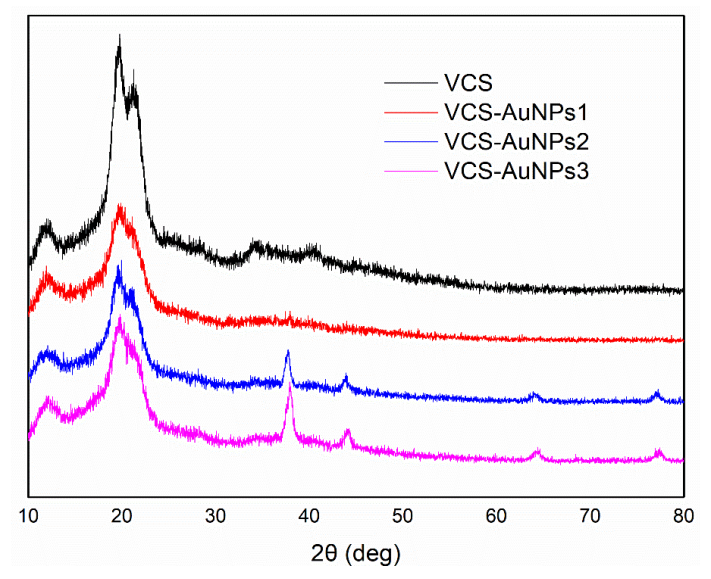

Figure 3. XRD analysis of VCS and AuNPs@VCS.

The transmission spectra of ATR-FTIR in the VCSs and AuNPs@VCSs are presented in Figure 4. After the thermal treatment, viscose (cellulose xanthogenate) transformed to cellulose, and the three crucial absorbance peaks appeared at wavenumber of $3316 \mathrm{~cm}^{-1}$ (broad), $2896 \mathrm{~cm}^{-1}$, and 1019 $\mathrm{cm}^{-1}$, which were attributed to the hydroxyl $(\mathrm{O}-\mathrm{H})$, methyl $(\mathrm{C}-\mathrm{H})$, and methoxy $(-\mathrm{C}-\mathrm{O}-)$ groups, respectively [39-41]. On the AuPNs@VCSs, new absorbance peaks were found at wavenumber of $1650 \mathrm{~cm}^{-1}$, which represents the vibration of carbonyl $(\mathrm{C}=\mathrm{O})$ in carboxylic groups [42]. The surface chemical compositions of VCSs and AuNPs@VCSs were further examined by XPS, and the results are shown in Figure 5. The XPS survey spectra of the VCSs and AuNPs@VCSs were observed (Figure 5a,b), and the O1s peaks were fitted by using several components (Figure $5 c, d$ ). The O1s spectra of VCS showed two peaks at 532.4 and $533.8 \mathrm{eV}$, which were related to $\mathrm{C}-\mathrm{OH}$ and $\mathrm{C}-\mathrm{O} /$ water. However, the O1s region of AuNPs@VCS showed one more peak than that of the VCS because of COOH at 531.6 eV $[43,44]$. Results of FTIR and XPS on the VCSs and AuNPs@VCSs confirmed that hydroxyl groups of cellulose were oxidized into carboxyl groups by $\mathrm{Au}^{3+}$.

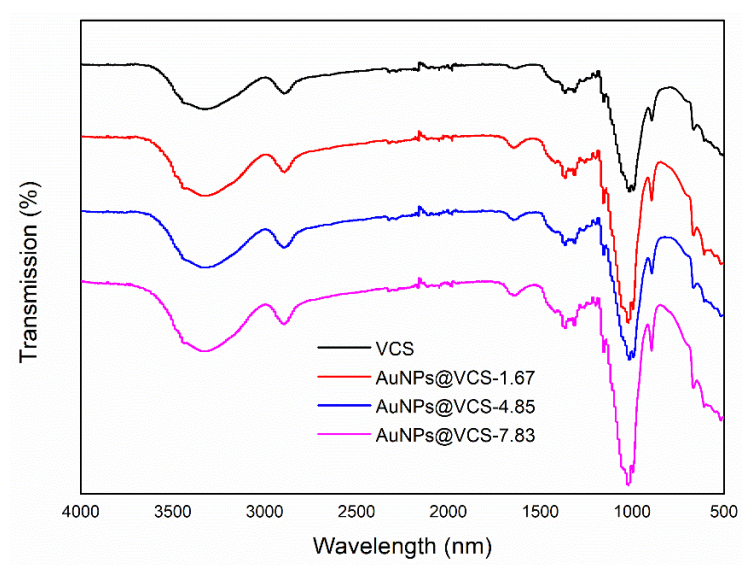

Figure 4. FTIR spectra for VCS and AuNPs@VCS. 

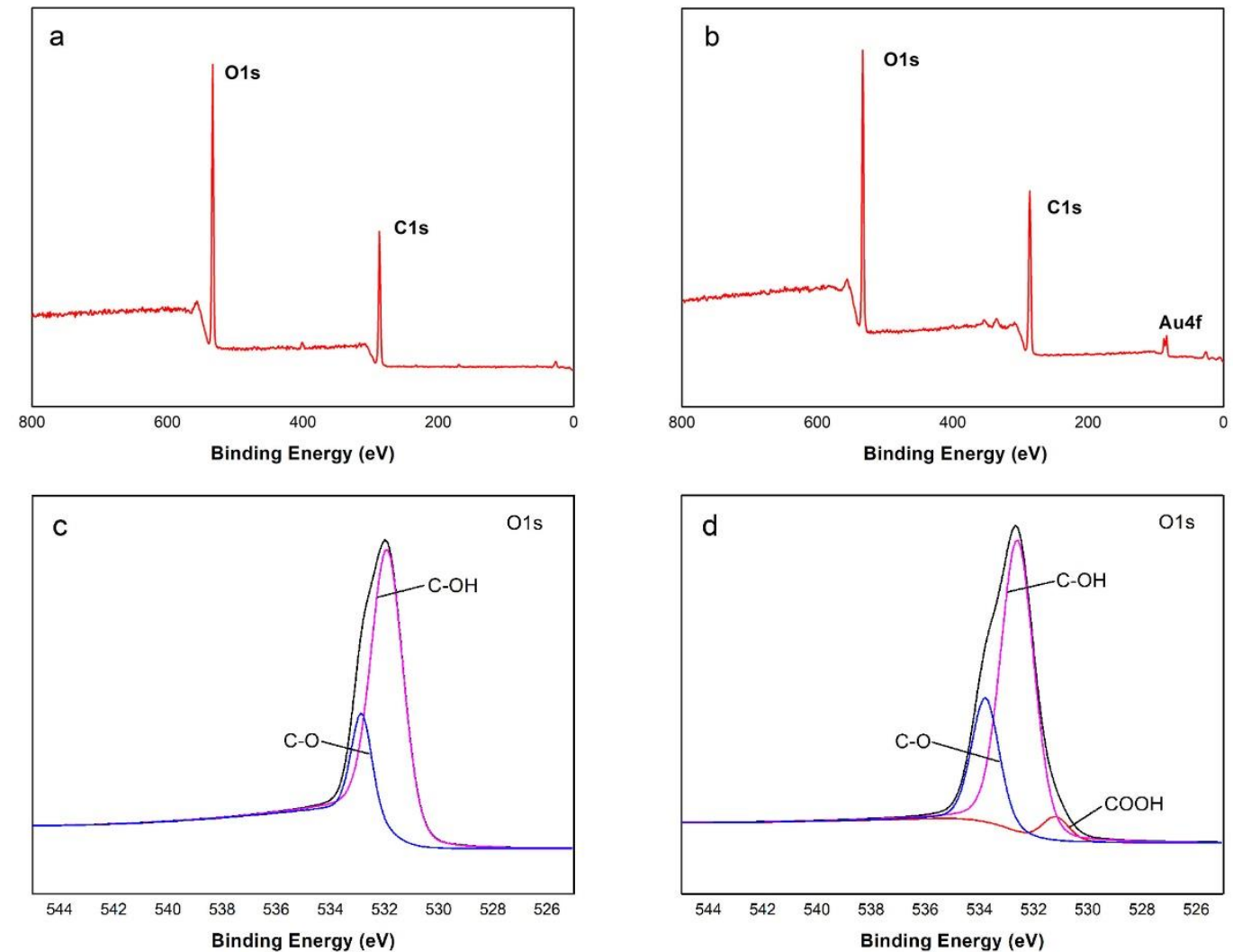

Figure 5. (a,b) XPS survey spectra of VCS and AuNPs@VCS. (c,d) High-resolution spectra of O1s of VCS and AuNPs@VCS.

\subsection{Properties of VCSs and AuNPs@VCSs}

The mechanical properties of VCSs and AuNPs@VCSs at room temperature are shown in Figure 6. The tensile strength values of the VCSs and AuNPs@VCSs were 0.15, 0.63, 0.79, and 0.98 MPa and the tensile strain values were $25.45 \%, 30.55 \%, 12.22 \%$, and $10.39 \%$, respectively. The findings showed that tensile strength improved with the increase in AuNPs. Strain increased first, then decreased. The results of mechanical properties show the enhancement effect of metal nanoparticles on VCSs, which is similar to the previous studies [32,45].

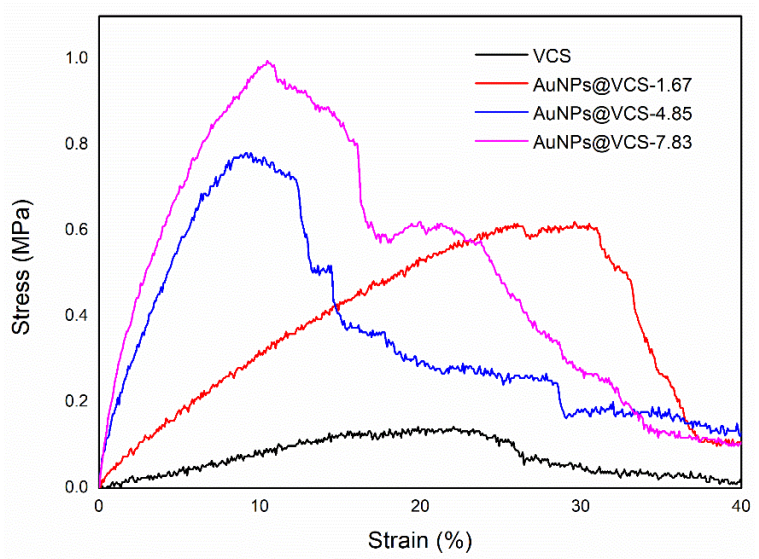

Figure 6. Strain-stress curves for extension test of VCS and AuNPs@VCS at room temperature.

The thermostability of the VCSs and AuNPs@VCSs was examined by TG curves under nitrogen atmosphere (Figure 7). The thermal decomposition of the VCSs was conducted in three main steps. 
The first weight loss, approximately $6.5 \mathrm{wt} . \%$, was observed from $30{ }^{\circ} \mathrm{C}$ to $100{ }^{\circ} \mathrm{C}$ and attributed to the loss of the physically bound water. The second weight loss, around $70.9 \mathrm{wt} . \%$, was from $207^{\circ} \mathrm{C}$ to $330{ }^{\circ} \mathrm{C}$, showed the degradation of the side chain groups of the cellulose fibers and the breaking of the main cellulose fibers into small chains. The third weight loss, approximately $19.6 \mathrm{wt} . \%$, observed from $330{ }^{\circ} \mathrm{C}$ to $500{ }^{\circ} \mathrm{C}$, was due to the complete thermal oxidation of the cellulose chains. As shown above, the thermogravimetric curve of the AuNPs@VCS was similar to that of the VCS. However, the second decomposition step was raised to $334^{\circ} \mathrm{C}, 339^{\circ} \mathrm{C}$, and $344^{\circ} \mathrm{C}$, which indicated the presence of thermally stable AuNPs and slightly improved thermostability of the AuNPs@VCSs. Meanwhile many previous studies have also shown similar results. The improvement of thermostability was attributed to the strong binding interaction between AuNPs and reducing polysaccharide [46,47].

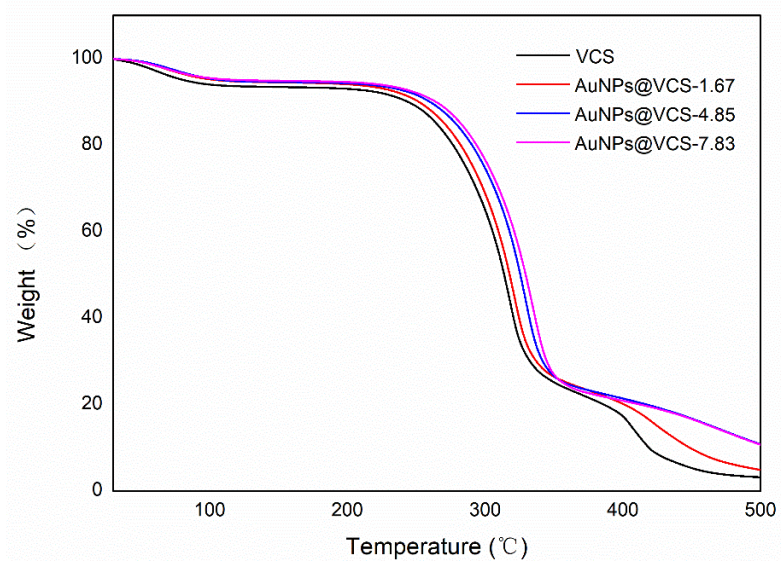

Figure 7. TG curves of VCS and AuNPs@VCS.

The efficiency of water absorption and water retention capacity are essential to antibacterial sponge. The water absorption and water retention capacities of different sponges are shown in Figure 8 . The water absorption capacities of the VCSs and AuNPs@VCSs were $1101 \%, 996 \%, 911 \%$, and $819 \%$ at increased AuNPs. Water retention capacities were $444 \%, 406 \%$, 388\%, and 346\% (Figure 8). The water absorption and water retention capacities of VCS and AuNPs@VCS decreased gradually. This decrease indicates that water-absorbing groups, such as the hydroxy groups of cellulose, decreased because of the oxidization of $\mathrm{Au}^{3+}$.

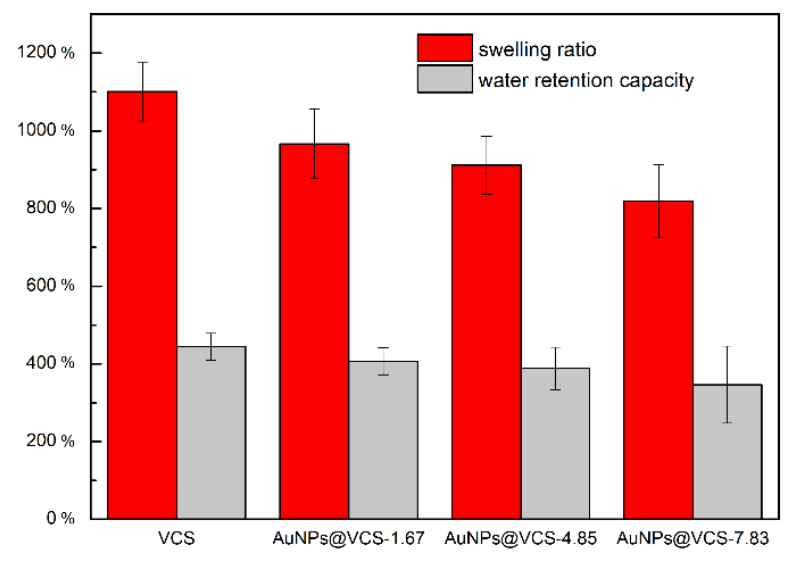

Figure 8. Swelling ratio and water retention capacity of VCS and AuNPs@VCS.

The antibacterial activities of VCS and AuNPs@VCS were measured against E. coli and S. aureus (Figure 9). VCS displayed no antibacterial activity against both bacteria, whereas the inhibition zones of AuNPs@VCS samples were observed after $24 \mathrm{~h}$ incubation. The AuNPs@VCSs exhibited notable antimicrobial efficacy against both bacteria. The average inhibition zone diameters of AuNPs@VCS 
against S. aureus widened from $31.4 \mathrm{~mm}$ to $37.1 \mathrm{~mm}$ and E. coli widened from $29.8 \mathrm{~mm}$ to $35.7 \mathrm{~mm}$ (Table 1). The distinctions of the VCS and AuNPs@VCS against Gram-negative bacteria E. coli and Gram-positive bacteria $S$. aureus could be attributable to the different structures of their cell wall. Compared with other antibacterial agents, AuNPs, due to their inherent physio-chemical properties, have lower biological toxicity $[48,49]$.
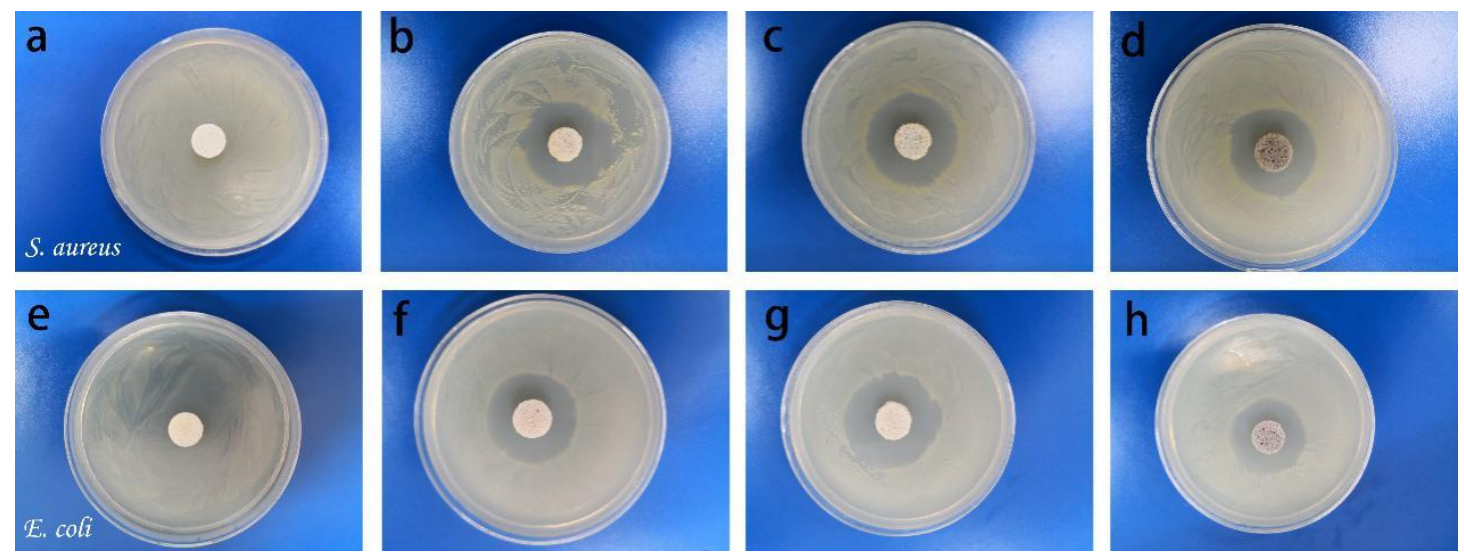

Figure 9. Inhibition zones of the VCS and different AuNPs@VCS against S. aureus (a-d) and E. coli (e-h) after incubation for $24 \mathrm{~h}$. The diameter of sponge samples is $14 \mathrm{~mm}$.

Table 1. Inhibition zone diameters ( $\mathrm{mm}$ ) of sponge samples against S. aureus and E. coli after incubation for $24 \mathrm{~h}$.

\begin{tabular}{ccccc}
\hline \multirow{2}{*}{ Bacterial Strain } & \multicolumn{4}{c}{ Diameter of Inhibition Zone (mm) } \\
\cline { 2 - 5 } & VCS & AuNPs@VCS-1.67 & AuNPs@VCS-4.85 & AuNPs@VCS-7.83 \\
\hline S. aureus & 0 & 33.4 & 35.7 & 29.8 \\
E. coli & 0 & 32.2 & 37.1 & 31.4 \\
\hline
\end{tabular}

AuNPs@VCS were treated at different media $\left(\mathrm{H}_{2} \mathrm{O}, \mathrm{NaOH}\right.$, and $\left.\mathrm{CH}_{3} \mathrm{COOH}\right)$ and examined with ultraviolet spectrum (Figure 10) for the evaluation of the stability of the AuNPs onto VCS. The sharp peaks centered at 510-560 $\mathrm{nm}$ attributed to AuNPs were not observed [34]. This result indicates that AuNPs can firmly combine with VCS and have good durability on VCS.

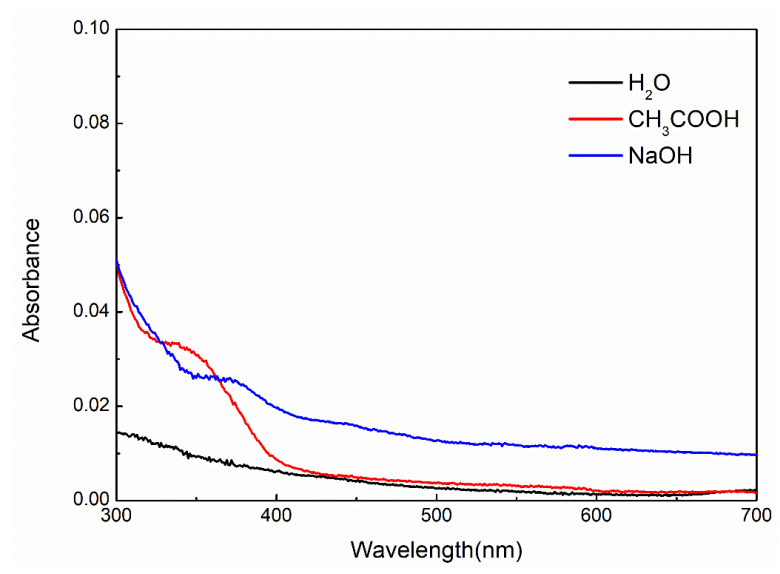

Figure 10. UV-Vis spectra of AuNPs@VCS-4.85 immersed in $\mathrm{H}_{2} \mathrm{O}, \mathrm{NaOH}$, and $\mathrm{CH}_{3} \mathrm{COOH}$.

\section{Conclusions}

Antibacterial cellulose sponges were completely formed with viscose for the in situ reduction of $\mathrm{HAuCl}_{4} \cdot \mathrm{nH}_{2} \mathrm{O}$ and stabilization of AuNPs through the hydrothermal method. XRD, FTIR, XPS, and 
SEM confirmed the formation of the AuNPs on VCS. AuNPs@VCS exhibited remarkable antibacterial properties, and the mechanical performance, thermal stability, and stability of the AuNPs were improved. The composite sponge can provide a new antibacterial material, which can be easily fabricated at the industrial level. The results can provide references for cleaning and sanitation fields owing to the advantage of cellulose and AuNPs.

Author Contributions: Conceptualization, X.Z., M.S., X.W. and C.L.; methodology, M.S., X.Z., L.S. and C.L.; investigation, C.L., L.Z., Y.L., S.Z. and Z.Z.; writing, X.Z. and C.L.; supervision, X.W., X.Z. and M.S.

Funding: The author would like to thank National Key R\&D Program of China (2017YFB0309303), National Natural Science Foundation of China (51603148), and the Science and Technology Plans of Tianjin (17JCYBJC17200, 17JCZDJC38100 and 18PTSYJC00180) for their financial supports.

Acknowledgments: We gratefully acknowledge Zhihua Wang of Tianjin University for her assistance in the antibacterial activity measurements.

Conflicts of Interest: The authors declare no conflict of interest.

\section{References}

1. Obradovic, J.; Voutilainen, M.; Virtanen, P.; Lassila, L.; Fardim, P. Cellulose Fibre-Reinforced Biofoam for Structural Applications. Materials 2017, 10, 619. [CrossRef]

2. Josset, S.; Hansen, L.; Orsolini, P.; Griffa, M.; Kuzior, O.; Weisse, B.; Zimmermann, T.; Geiger, T. Microfibrillated cellulose foams obtained by a straightforward freeze-thawing-drying procedure. Cellulose 2017, 24, 3825-3842. [CrossRef]

3. Klemm, D.; Heublein, B.; Fink, H.P.; Bohn, A. Cellulose: Fascinating Biopolymer and Sustainable Raw Material. Angew. Chem. Int. Edit. 2005, 44, 3358-3393. [CrossRef]

4. Yang, Y.J.; Shin, J.M.; Kang, T.H.; Kimura, S.; Wada, M.; Kim, U.J. Cellulose dissolution in aqueous lithium bromide solutions. Cellulose 2014, 21, 1175-1181. [CrossRef]

5. Swatloski, R.P.; Spear, S.K.; Holbrey, J.D.; Rogers, R.D. Dissolution of Cellose with Ionic Liquids. J. Am. Chem. Soc. 2002, 124, 4974-4975. [CrossRef]

6. Isogai, A.; Atalla, R.H. Dissolution of cellulose in aqueous $\mathrm{NaOH}$ solutions. Cellulose 1998, 5, 309-319. [CrossRef]

7. Dogan, H.; Hilmioglu, N.D. Dissolution of cellulose with NMMO by microwave heating. Carbohyd. Polym. 2009, 75, 90-94. [CrossRef]

8. Heinze, T.; Dicke, R.; Koschella, A.; Kull, A.H.; Klohr, E.A.; Koch, W. Effective preparation of cellulose derivatives in a new simple cellulose solvent. Macromol. Chem. Phys. 2000, 201, 627-631. [CrossRef]

9. Zhao, H.B.; Kwak, J.H.; Wang, Y.; Franz, J.A.; White, J.M.; Holladay, J.E. Interactions between cellulose and N-methylmorpholine-N-oxide. Carbohyd. Polym. 2007, 67, 97-103. [CrossRef]

10. Cai, J.; Zhang, L. Rapid Dissolution of Cellulose in $\mathrm{LiOH} / \mathrm{Urea}$ and $\mathrm{NaOH} / \mathrm{Urea}$ Aqueous Solutions. Macromol. Biosci. 2005, 5, 539-548. [CrossRef]

11. Matsumoto, T.; Tatsumi, D.; Tamai, N.; Takaki, T. Solution properties of celluloses from different biological origins in LiCl · DMAc. Cellulose 2001, 8, 275-282. [CrossRef]

12. Heinze, T.; Koschella, A. Solvents Applied in the Field of Cellulose Chemistry-A Mini Review. Polimeros 2005, 15, 84-90. [CrossRef]

13. Li, R.; Du, J.Y.; Zheng, Y.M.; Wen, Y.Q.; Zhang, X.X.; Yang, W.B.; Lue, A.; Zhang, L.N. Ultra-lightweight cellulose foam material: Preparation and properties. Cellulose 2017, 24, 1417-1426. [CrossRef]

14. Peng, H.L.; Wang, H.; Wu, J.N.; Meng, G.H.; Wang, Y.X.; Shi, Y.L.; Liu, Z.Y.; Guo, X.H. Preparation of Superhydrophobic Magnetic Cellulose Sponge for Removing Oil from Water. Ind. Eng. Chem. Res. 2016, 55, 832-838. [CrossRef]

15. Zheng, C.; Li, D.F.; Ek, M. Improving fire retardancy of cellulosic thermal insulating materials by coating with bio-based fire retardants. Nord. Pulp. Pap. Res. J. 2019, 34, 96-106. [CrossRef]

16. Nechita, P.; Nastac, S. Foam-formed cellulose composite materials with potential applications in sound insulation. J. Compos. Mater. 2017, 52, 747-754. [CrossRef]

17. Ganjyal, G.M.; Reddy, N.; Yang, Y.Q.; Hanna, M.A. Biodegradable packaging foams of starch acetate blended with corn stalk fibers. J. Appl. Polym. Sci. 2004, 93, 2627-2633. [CrossRef] 
18. Uysal, A.C.; Alagoz, M.S.; Orbay, H.; Sensoz, O. An Alternative Dressing Material for the Split-Thickness Skin Graft Donor Site-Oxidized regenerated cellulose. Ann. Plas. Surg. 2006, 57, 60-64. [CrossRef]

19. Wang, S.; Lu, A.; Zhang, L.N. Recent advances in regenerated cellulose materials. Prog. Polym. Sci. 2016, 53, 169-206. [CrossRef]

20. Pulit-Prociak, J.; Chwastowski, J.; Kucharski, A.; Banach, M. Functionalization of textiles with silver and zinc oxide nanoparticles. Appl. Surf. Sci. 2016, 385, 543-553. [CrossRef]

21. Makvandi, P.; Nikfarjam, N.; Sanjani, N.S.; Qazvini, N.T. Effect of silver nanoparticle on the properties of poly(methyl methacrylate) nanocomposite network made by in situ photoiniferter-mediated photopolymerization. Bull. Mater. Sci. 2015, 38, 1625-1631. [CrossRef]

22. Dizaj, S.M.; Lotfipour, F.; Barzegar-Jalali, M.; Zarrintan, M.H.; Adibkia, K. Antimicrobial activity of the metals and metal oxide nanoparticles. Mater. Sci. Eng. C Mater. 2014, 44, 278-284. [CrossRef]

23. Bagchi, B.; Kar, S.; Dey, S.K.; Bhandary, S.; Roy, D.; Mukhopadhyay, T.K.; Das, S.; Nandy, P. In situ synthesis and antibacterial activity of copper nanoparticle loaded natural montmorillonite clay based on contact inhibition and ion release. Colloid. Surface B 2013, 108, 358-365. [CrossRef]

24. Fan, Z.; Liu, B.; Wang, J.Q.; Zhang, S.Y.; Lin, Q.Q.; Gong, P.W.; Ma, L.M.; Yang, S.R. A Novel Wound Dressing Based on Ag/Graphene Polymer Hydrogel: Effectively Kill Bacteria and Accelerate Wound Healing. Adv. Funct. Mater. 2014, 24, 3933-3943. [CrossRef]

25. He, W.W.; Kim, H.K.; Warner, W.G.; Melka, D.; Callahan, J.H.; Yin, J.J. Photogenerated Charge Carriers and Reactive Oxygen Species in $\mathrm{ZnO} / \mathrm{Au}$ Hybrid Nanostructures with Enhanced Photocatalytic and Antibacterial Activity. J. Am. Chem. Soc. 2014, 136, 750-757. [CrossRef]

26. Mahmoud, N.N.; Hikmat, S.; Ghith, D.A.; Hajeer, M.; Hamadneh, L.; Qattan, D.; Khalil, E.A. Gold nanoparticles loaded into polymeric hydrogel for wound healing in rats: Effect of nanoparticles' shape and surface modification. Int. J. Pharmaceut. 2019, 565, 174-186. [CrossRef]

27. Wang, D.W.; Lagzi, I.; Wesson, P.J.; Grzybowski, B.A. Rewritable and pH-Sensi; tive Micropatterns Based on Nanoparticle "Inks". Small 2010, 6, 2114-2116. [CrossRef]

28. Zhuang, X.P.; Cheng, B.W.; Kang, W.M.; Xu, X.L. Electrospun chitosan/gelatin nanofibers containing silver nanoparticles. Carbohyd. Polym. 2010, 82, 524-527. [CrossRef]

29. Emam, H.E.; El-Hawary, N.S.; Ahmed, H.B. Green technology for durable finishing of viscose fibers via self-formation of AuNPs. Int. J. Biol. Macromol. 2017, 96, 697-705. [CrossRef]

30. Elmaaty, T.A.; El-Nagare, K.; Raouf, S.; Abdelfattah, K.; El-Kadi, S.; Abdelaziz, E. One-step green approach for functional printing and finishing of textiles using silver and gold NPs. RSC Adv. 2018, 8, 25546-25557. [CrossRef]

31. Wei, H.R.; Rodriguez, K.; Renneckar, S.; Leng, W.N.; Vikesland, P.J. Preparation and Evaluation of Nanocellulose-Gold Nanoparticle Nanocomposites for SERS Applications. Analyst 2015, 140, 5640-5649. [CrossRef]

32. Ye, D.D.; Zhong, Z.B.; Chang, C.Y.; Yang, Z.X.; Wang, Y.F.; Ye, Q.F.; Zhang, L.N. Construction of cellulose/nanosilver sponge materials and their antibacterial activities for infected wounds healing. Cellulose 2016, 23, 749-763. [CrossRef]

33. Dankovich, T.A.; Gray, D.G. Bactericidal Paper Impregnated with Silver Nanoparticles for Point-of-Use Water Treatment. Environ. Sci. Technol. 2011, 45, 1992-1998. [CrossRef]

34. Sugunan, A.; Thanachayanont, C.; Dutta, J.; Hilborn, J.G. Heavy-metal ion sensors using chitosan-capped gold nanoparticles. Sci. Technol. Adv. Mater. 2005, 6, 335-340. [CrossRef]

35. Sayyed, A.J.; Deshmukh, N.A.; Pinjari, D.V. A critical review of manufacturing processes used in regenerated cellulosic fibres: Viscose, cellulose acetate, cuprammonium, $\mathrm{LiCl} / \mathrm{DMAc}$, ionic liquids, and NMMO based lyocell. Cellulose 2019, 26, 2913-2940. [CrossRef]

36. Xu, Y.; Lu, Z.; Tang, R. Structure and thermal properties of bamboo viscose, Tencel and conventional viscose fiber. J. Therm. Anal. Calorim. 2007, 89, 197-201. [CrossRef]

37. Zhang, P.; Li, J.X.; Liu, D.F.; Qin, Y.J.; Guo, Z.X.; Zhu, D.B. Self-Assembly of Gold Nanoparticles on Fullerene Nanospheres. Langmuir 2004, 20, 1466-1472. [CrossRef]

38. Jiang, G.; Wang, L.; Chen, W.X. Studies on the preparation and characterization of gold nanoparticles protected by dendrons. Mater. Lett. 2007, 61, 278-283. [CrossRef]

39. Emam, H.E.; Bechtold, T. Cotton fabrics with UV blocking properties through metal salts deposition. Appl. Surf. Sci. 2015, 357, 1878-1889. [CrossRef] 
40. Ahmed, H.B.; Emam, H.E. Layer by layer assembly of nanosilver for high performance cotton fabrics. Fiber. Polym. 2016, 17, 418-426. [CrossRef]

41. Abdelhameed, R.M.; Abdel-Gawad, H.; Elshahat, M.; Emam,H.E.Cu-BTC@cotton composite: Design and removal of ethion insecticide from water. RSC Adv. 2016, 6, 42324-42333. [CrossRef]

42. Xu, X.L.; Li, R.; Tang, C.X.; Wang, H.; Zhuang, X.P.; Liu, Y.; Kang, W.M.; Shi, L. Cellulose nanofiber-embedded sulfonated poly(ether sulfone) membranes for proton exchange membrane fuel cells. Carbohydr. Polym. 2018, 184, 299-306. [CrossRef]

43. Moreira, G.F.; Pecanha, E.R.; Monte, M.B.M.; Leal, L.S.; Stavale, F. XPS study on the mechanism of starch-hematite surface chemical complexation. Miner. Eng. 2017, 110, 96-103. [CrossRef]

44. Lubenchenko, A.V.; Batrakov, A.A.; Pavolotsky, A.B.; Lubenchenko, O.I.; Ivanov, D.A. XPS study of multilayer multicomponent films. Appl. Surf. Sci. 2018, 427, 711-721. [CrossRef]

45. Celikkin, N.; Mastrogiacomo, S.; Walboomers, X.F.; Swieszkowski, W. Enhancing X-ray Attenuation of 3D Printed Gelatin Methacrylate (GelMA) Hydrogels Utilizing Gold Nanoparticles for Bone Tissue Engineering Applications. Polym. Basel 2019, 11, 367. [CrossRef]

46. Meng, Y.; Cai, L.Q.; Xu, X.J.; Zhang, L.N. Construction of size-controllable gold nanoparticles immobilized on polysaccharide nanotubes by in situ one-pot synthesis. Int. J. Biol. Macromol. 2018, 113, 240-247. [CrossRef]

47. Konowal, E.; Modrzejewska-Sikorska, A.; Motylenko, M.; Klapiszewski, L.; Wysokowski, M.; Bazhenov, V.V.; Rafaja, D.; Ehrlich, H.; Milczarek, G.; Jesionowski, T. Functionalization of organically modified silica with gold nanoparticles in the presence of lignosulfonate. Int. J. Biol. Macromol. 2016, 85, 74-81. [CrossRef]

48. Tiwari, P.M.; Vig, K.; Dennis, V.A.; Singh, S.R. Functionalized Gold Nanoparticles and Their Biomedical Applications. Nanomater. Basel 2011, 1, 31-63. [CrossRef]

49. Ibrahim, N.A.; Eid, B.M.; Abdel-Aziz, M.S. Green synthesis of AuNPs for eco-friendly functionalization of cellulosic substrates. Appl. Surf. Sci. 2016, 389, 118-125. [CrossRef]

(C) 2019 by the authors. Licensee MDPI, Basel, Switzerland. This article is an open access article distributed under the terms and conditions of the Creative Commons Attribution (CC BY) license (http://creativecommons.org/licenses/by/4.0/). 